\title{
Correction to: Chronological evolution of the channel functional units in association with palaeo-hydrogeomorphological environment in the ancient delta fan of Subarnarekha basin, India
}

\author{
Subrata Jana ${ }^{1}$ (D) Ashis Kumar Paul ${ }^{1}$
}

Published online: 30 July 2020

๑) Springer-Verlag GmbH Germany, part of Springer Nature 2020

Correction to: Environmental Earth Sciences (2020) 79:331 https://doi.org/10.1007/s12665-020-09093-1

The original article has been published inadvertently with some errors in figures and their caption (Figs. 1, 2, 3, 5) and errors only in captions of figures (Figs. 4, 6, 7, 8, 9), also errors in tables and their caption (Tables 1, 5, 6, 7) and errors only in captions of tables (Tables 2, 3). All the corrected versions of figures and tables (with captions) are given below. 


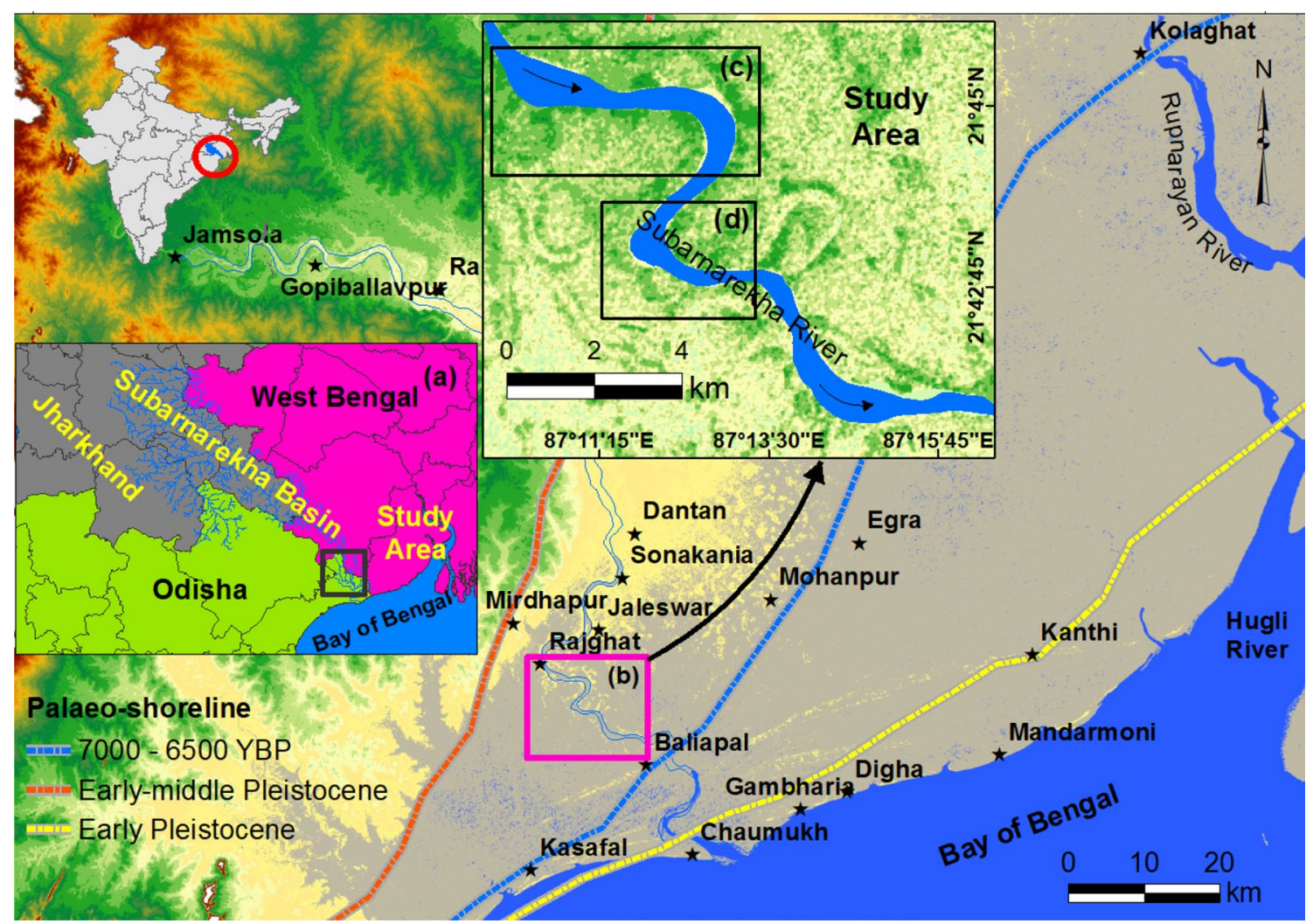

Fig. 1 Regional settings of the Subarnarekha deltaplain and position of palaeo-shorelines. Within the Subarnarekha river basin $(a)$ the study area situated in the ancient delta fan region $(b)$. The positions of river course in the downstream section of Rajghat $(c)$ and in Asti section $(d)$ have been considered for micro-morphological change analysis of the channel unit 


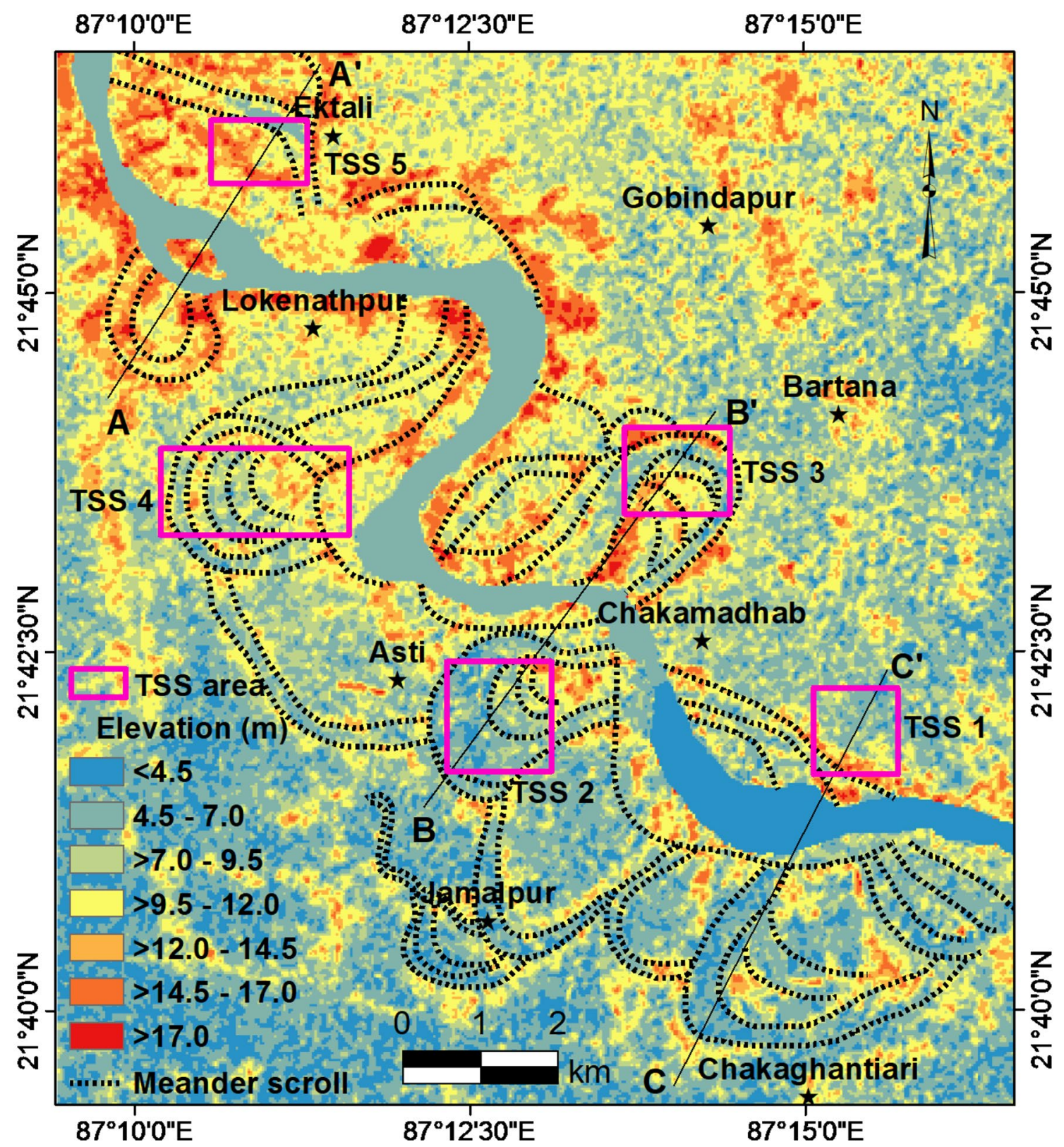

Fig. 2 Landscape composed of upper (> $12 \mathrm{~m})$, middle (7-9.5 m), and lower $(<7 \mathrm{~m})$ terraces in the lower Subarnarekha river basin. Palaeo meander scrolls aligned over middle-lower terraces. Five dif- ferent areas of total station survey (TSS 1 to 5) have been indicated by rectangles. $A A^{\prime}, B B^{\prime}$ and $C C^{\prime}$ are the position of cross-valley transects for analysis of micro-landforms 


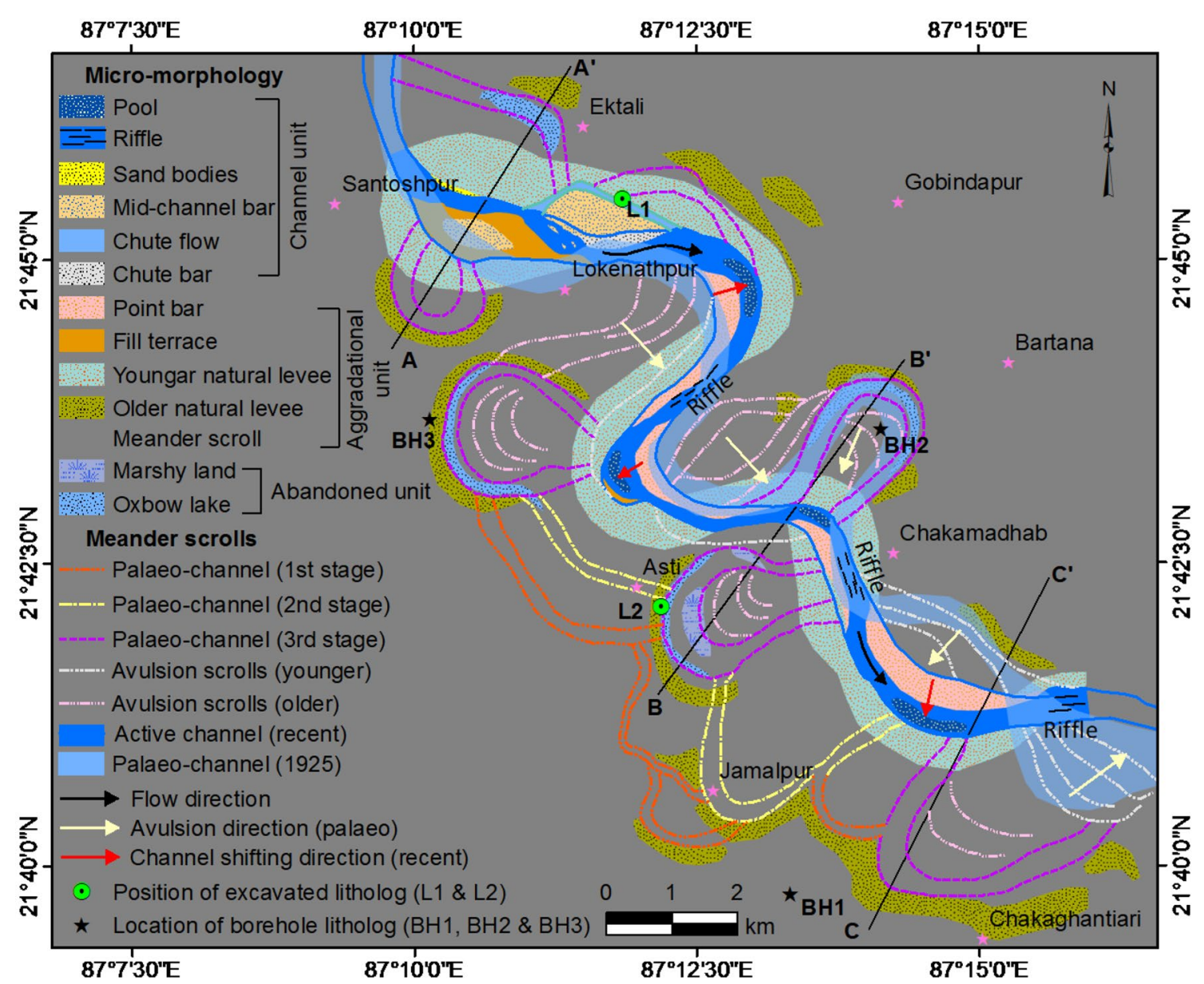

Fig. 3 Channel functional units with distinct micro-morphological features sculpted by avulsion processes during the past and recent period. $A A^{\prime}, B B^{\prime}$ and $C C^{\prime}$ are the cross-valley transects

Fig. 4 Micro-geomorphological changes of the channel unit during 2007-2014 in the downstream section of Rajghat. The position of river course is demarcated in Fig. 1c. 

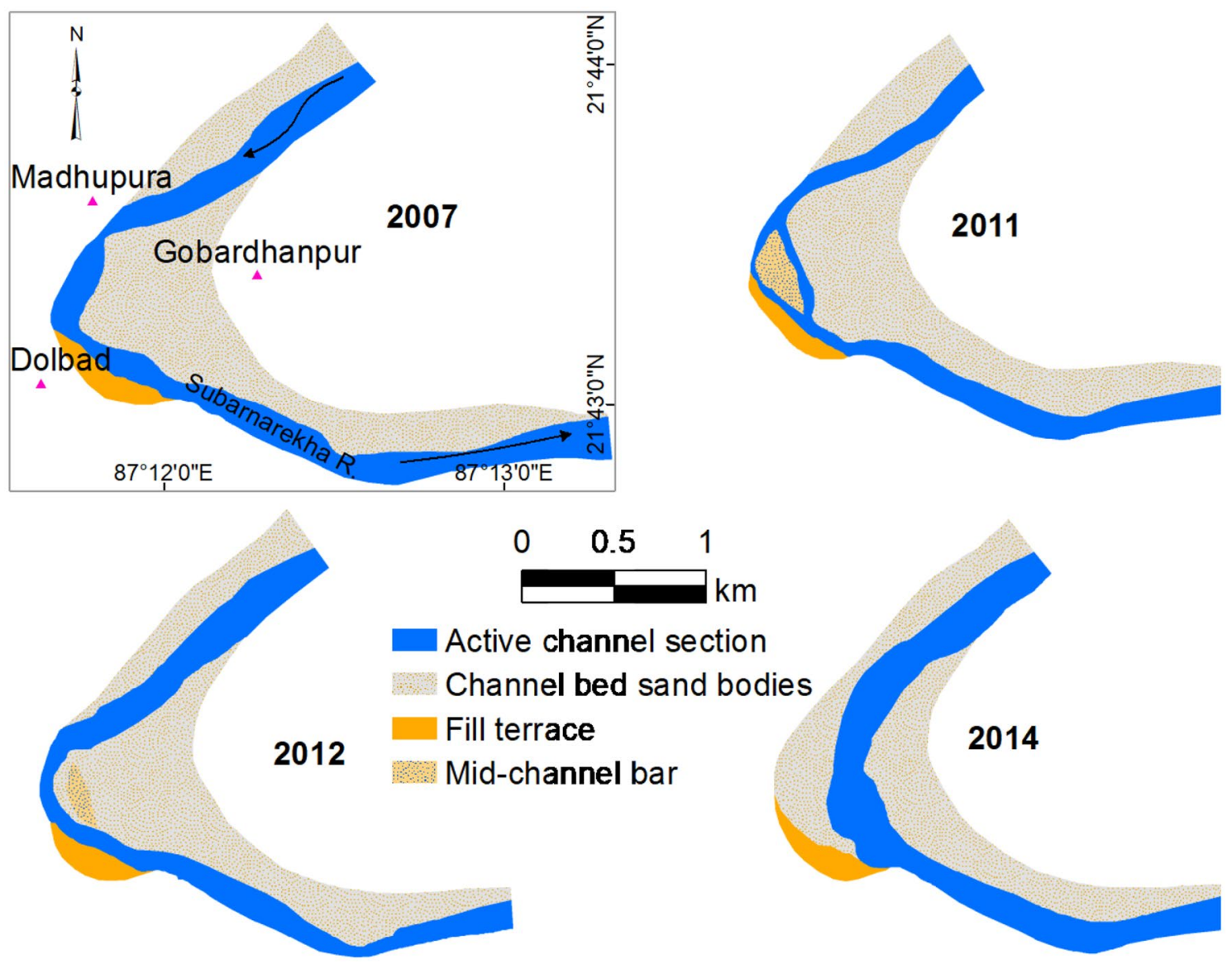

Fig. 5 Micro-geomorphological changes of the channel unit during 2007-2014 in the Asti section near Baliapal. The position of river course is demarcated in Fig. 1d

Fig. 6 Cross-sectional form of micro-landforms terraces discriminate the recent and palaeo-courses of the Subarnarekha river in three defined sections $\left(\mathrm{AA}^{\prime}, \mathrm{BB}^{\prime}\right.$ and $\left.\mathrm{CC}^{\prime}\right)$, mentioned in Figs. 2 and 3.

Fig. 7 Yearwise distribution and trend of mean gauge height at the Rajghat gauge station and annual average sediment load at the Ghatshila gauge station of the Subarnarekha River during 1973-2012.
Fig. 8 Lithostratigraphic structure of sedimentary profiles of younger (L1) and older (L2) natural levee sites. Both photographs at top (a) and bottom (b) are the part of the same cross section of L1, which shows brownish-to-grayish colour. The positions of L1 and L2 mentioned in Fig. 3.

Fig. 9 Borehole lithostratigraphic structures and depositional environments of the ancient delta fan. The borehole locations are indicated in Fig. 3. 


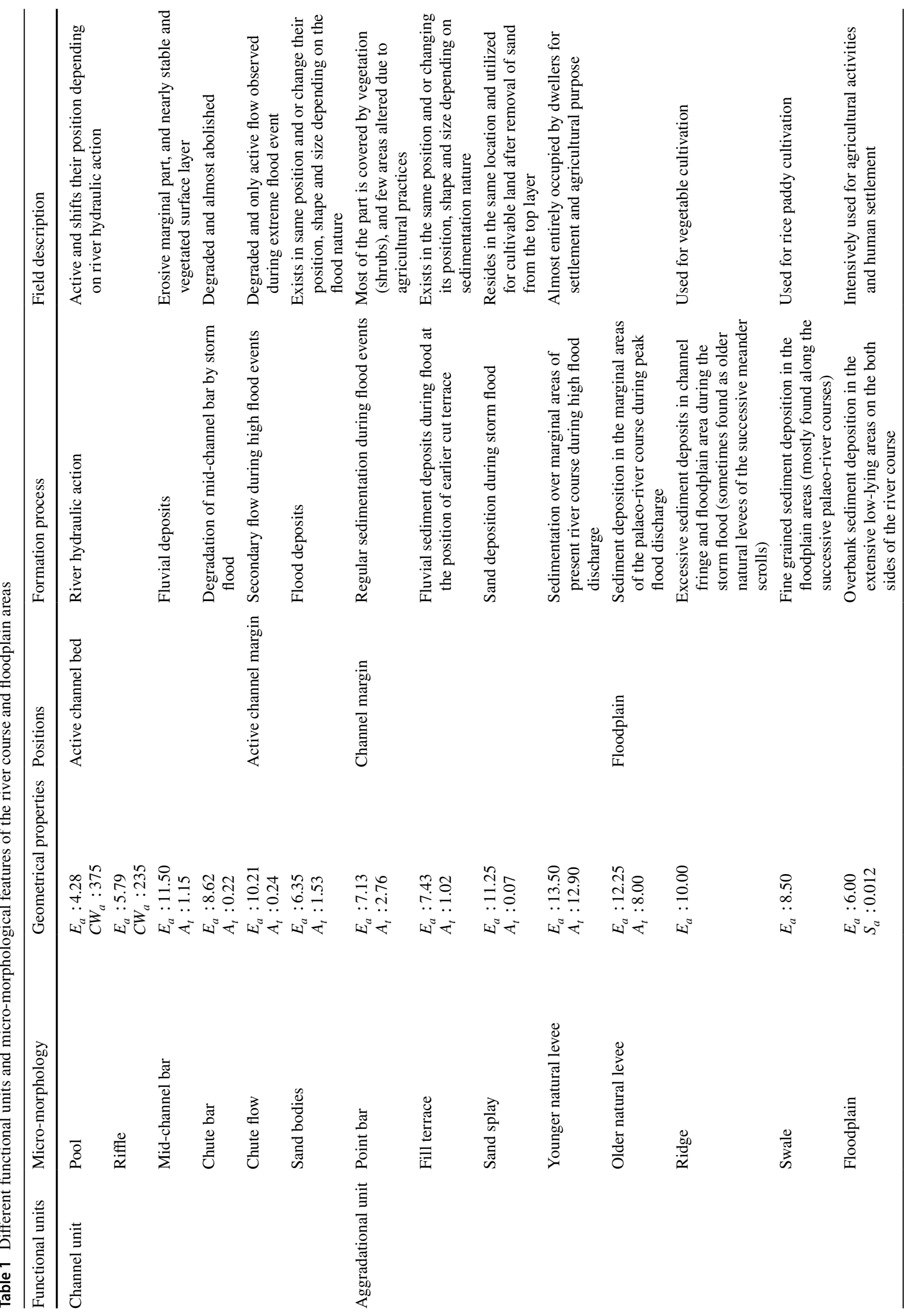




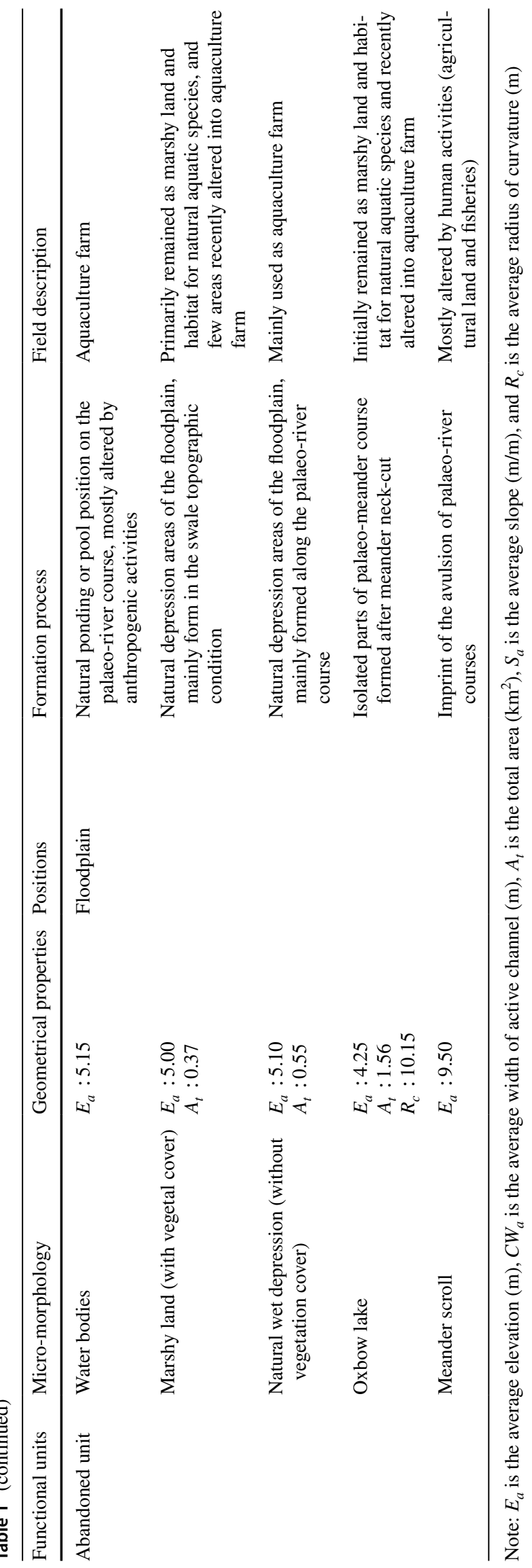

Table 2 Changing nature of different micro-morphological features of the downstream section of Rajghat (based on Fig. 4).

Table 3 Changing nature of different micro-morphological features of the Asti section near Baliapal (based on Fig. 3). 
Table 5 Sedimentary characteristics of different layers of the excavated profile of older natural levee (L2)

\begin{tabular}{|c|c|c|c|c|c|c|c|c|c|}
\hline Layer & $\begin{array}{l}\text { Depth (m. } \\
\text { bgl) }\end{array}$ & $\begin{array}{l}\text { Material } \\
\text { types }\end{array}$ & $\begin{array}{l}\text { Structure/ } \\
\text { fossil }\end{array}$ & Colour & $\begin{array}{l}\text { Mean } \\
\text { grain-size } \\
(\mu \mathrm{m})\end{array}$ & Mode & Sorting & Skewness & Kurtosis \\
\hline 1st (top) & $0.0-1.10$ & $\begin{array}{l}\text { Medium- } \\
\text { coarse silt }\end{array}$ & $\begin{array}{l}\text { Horizontal } \\
\text { planar lami- } \\
\text { nation }\end{array}$ & Brownish & 16.21 & Unimodal & $\begin{array}{l}\text { Moderately } \\
\text { well sorted }\end{array}$ & Coarse & Platykurtic \\
\hline 2nd & $1.11-2.30$ & $\begin{array}{l}\text { Medium-fine } \\
\text { sand }\end{array}$ & $\begin{array}{l}\text { Trough cross } \\
\text { bedding }\end{array}$ & Grayish & 232.14 & Bimodal & $\begin{array}{l}\text { Moderately } \\
\text { well sorted }\end{array}$ & Coarse & Mesokurtic \\
\hline $3 r d$ & $2.31-3.80$ & Mud & $\begin{array}{c}\text { Decomposed } \\
\text { root (Avi- } \\
\text { cennia } \mathrm{sp} .)\end{array}$ & Dark brown & 1.22 & Unimodal & Well sorted & Symmetrical & Platykurtic \\
\hline 4th & $3.81-4.75$ & $\begin{array}{l}\text { Coarse- } \\
\text { medium } \\
\text { sand }\end{array}$ & $\begin{array}{l}\text { Trough cross } \\
\text { bedding }\end{array}$ & Blackish gray & 402.16 & Bimodal & $\begin{array}{l}\text { Moderately } \\
\text { well sorted }\end{array}$ & Fine & Leptokurtic \\
\hline 5 th & $4.76-5.61$ & Sticky clay & $\begin{array}{l}\text { Shells } \\
\text { (Ammonia } \\
\text { sp.) and } \\
\text { decomposed } \\
\text { root (Acros- } \\
\text { tichum } \\
\text { aureum) }\end{array}$ & Dark black & 0.42 & Unimodal & $\begin{array}{l}\text { Moderately } \\
\text { sorted }\end{array}$ & Symmetrical & Platykurtic \\
\hline 6th (bottom) & $\begin{array}{l}5.62-6.11 \text { (up } \\
\text { to excavated } \\
\text { layer) }\end{array}$ & Coarse silt & $\begin{array}{l}\text { Decomposed } \\
\text { root (Acros- } \\
\text { tichum } \\
\text { aureum) }\end{array}$ & Blackish gray & 21.31 & Unimodal & $\begin{array}{l}\text { Moderately } \\
\text { well sorted }\end{array}$ & Symmetrical & Mesokurtic \\
\hline
\end{tabular}




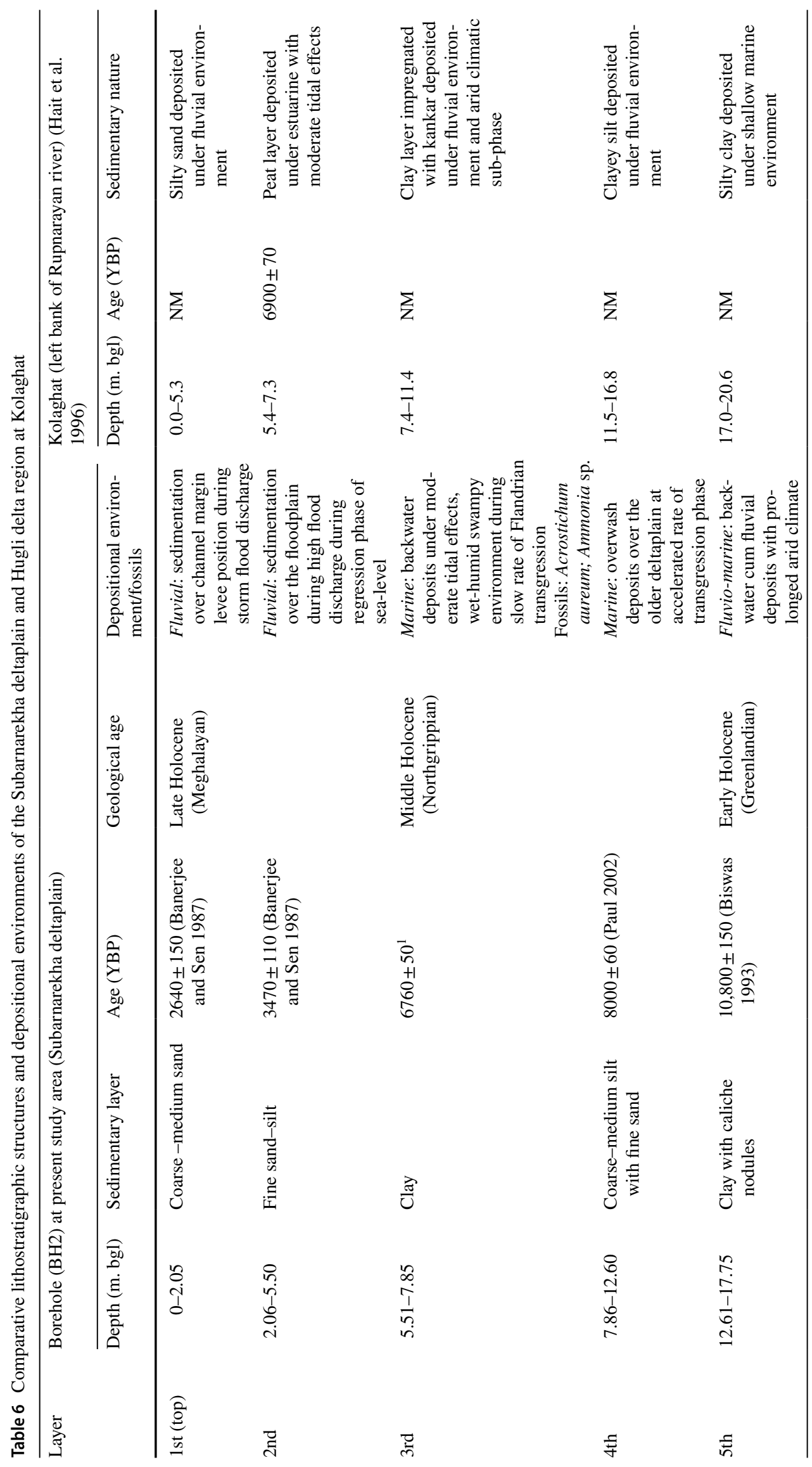




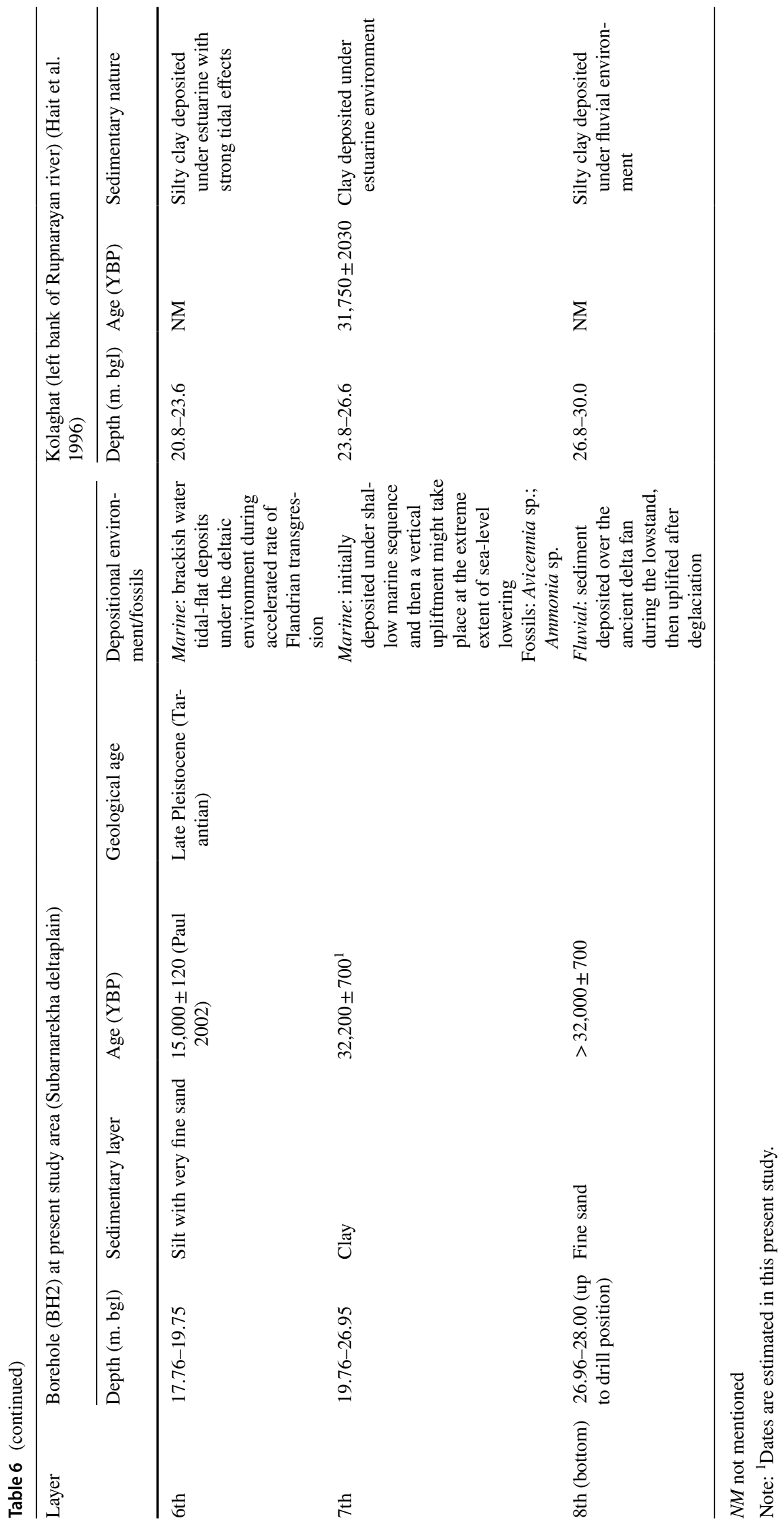


Table 7 Micro-landforms of the functional units and quaternary processes

\begin{tabular}{llc}
\hline Landforms & Age (YBP) & Process of formation \\
\hline $\begin{array}{l}\text { Channel unit (pool, riffle, sand bodies, mid-channel } \\
\text { bar, chute flow, chute bar) }\end{array}$ & Around 600-recent period & $\begin{array}{c}\text { Fluctuating discharge of water and sediment and } \\
\text { their interactions in diverse riverbed morphol- } \\
\text { ogy }\end{array}$ \\
$\begin{array}{l}\text { Aggradational unit (point bar, fill terrace, younger } \\
\text { natural levee, older natural levee) }\end{array}$ & $2640 \pm 150$ (Banerjee and Sen 1987) & $\begin{array}{c}\text { Channel avulsion and sedimentation coupled with } \\
\text { fluctuating discharge and base level of erosion } \\
\text { Abandoned unit (marshy land, oxbow lake, meander } \\
\text { cutoff) }\end{array}$ \\
& $4810 \pm 120$ (Niyogi 1975) & $\begin{array}{c}\text { Departing the river from palaeo-course to a new } \\
\text { course with due effects from extreme discharge } \\
\text { and valley cutting during marine regression } \\
\text { phase }\end{array}$ \\
\hline
\end{tabular}

Note: Older natural levee of the aggradational unit was formed around 6000-5000 YBP.

Publisher's Note Springer Nature remains neutral with regard to jurisdictional claims in published maps and institutional affiliations. 